\title{
Faktor risiko yang berhubungan dengan timbulnya nyeri punggung bawah pada guru SD di Kecamatan Tuminting
}

\author{
${ }^{1}$ Yanty Haumahu \\ ${ }^{2}$ Diana V. D. Doda \\ ${ }^{2}$ Sylvia R. Marunduh
}

\author{
${ }^{1}$ Kandidat Skripsi Fakultas Kedokteran Universitas Sam Ratulangi Manado \\ ${ }^{2}$ Bagian Fisiologi Fakultas Kedokteran Universitas Sam Ratulangi Manado \\ Email: yhaumahu12175@yahoo.com
}

\begin{abstract}
Work-related musculoskeletal disorder (WMSD) is one of the biggest problems in developing countries. According to the Department of Health of Indonesia about health problems in Indonesia in 2005, 40.5\% of illness were work-related. A study on 9482 workers in 12 districts in Indonesia reported that $16 \%$ of common illness was musculoskeletal diseases. This study aimed to determine the musculoskeletal disease (low back pain) during the last 7 days among elementary school teachers at Tuminting. This was a field study with a cross sectional design. Instruments were Nordic Body Map Question, physical exposure, and psychosocial questionnaire. The results showed that were 282 respondents in this study. The respond rate was $78 \%$. There were $81 \%$ of respondents withg low back pain. Significant associated risk factors were as follows: class level taught by respondents $(p=0.008)$; bending while arms were below the knees more than 30 minutes $(\mathrm{p}=0.049)$; leisure time activities during last 7 days $(\mathrm{p}=0.024)$; disruption/interruption $(\mathrm{p}=0.003)$; low job promotion $(\mathrm{p}=$ $0.032)$; unpleasant changes in workplace $(\mathrm{p}=0.003)$; and work-environment satisfaction $(\mathrm{p}=$ 0.003). Conclusion: Risk factors associated with low back pain among elementary school teachers at Tuminting were individual, physical, and psychosocial factors.
\end{abstract}

Keywords: low back pain, risk factor, elementary school teacher

\begin{abstract}
Abstrak: Penyakit muskuloskeletal terkait pekerjaan merupakan salah satu masalah terbesar di negara industri. Studi Departemen Kesehatan RI tentang profil masalah kesehatan di Indonesia tahun 2005 menunjukkan bahwa sekitar 40,5\% penyakit yang diderita berhubungan dengan pekerjaan. Studi yang dilakukan terhadap 9482 pekerja di 12 kabupaten di Indonesia mendapatkan $16 \%$ dari penyakit yang diderita secara umum ialah penyakit muskuloskeletal. Jenis penelitian ini ialah survei lapangan dengan desain potong lintang. Kuesioner yang digunakan ialah Nordic Body Map Question, paparan fisik, dan psikososial. Penelitian ini bertujuan untuk mengetahui penyakit muskuloskeletal (nyeri punggung bawah) dalam 7 hari terakhir pada guru SD di kecamatan Tuminting. Sebanyak 282 responden berpartisipasi dengan respond rate 78\%. Ditemukan 81\% responden mengalami nyeri punggung bawah. Faktor-faktor yang berhubungan signifikan antara lain kelas yang diajar $(p=0,008)$, membungkuk dengan tangan dibawah lutut lebih dari 30 menit $(\mathrm{p}=0,049)$, aktivitas waktu senggang dalam 7 hari terakhir $(p=0,024)$, adanya interupsi/gangguan $(p=0,003)$, harapan kenaikan pangkat yang buruk $(\mathrm{p}=0,032)$, perubahan tidak menyenangkan di tempat kerja $(\mathrm{p}=$ $0,003)$, dan kondisi lingkungan fisik $(\mathrm{p}=0,008)$. Simpulan: Faktor risiko yang berhubungan dengan nyeri punggung bawah dalam penelitian ini meliputi faktor individu, faktor fisik, dan faktor psikososial.
\end{abstract}

Kata kunci: nyeri punggung bawah, faktor risiko, guru sekolah dasar 
Work-related musculoskeletal disorders (WMSD) merupakan salah satu masalah terbesar di negara industri. Menurut WHO, WMSD merupakan multifaktorial dimana terdapat beberapa faktor risiko yang berkontribusi. The $4^{\text {th }}$ Europian Working Conditions Survey menyatakan bahwa 60 juta pekerja dilaporkan mengalami WMSD di Eropa. Nyeri punggung merupakan masalah kesehatan yang paling sering terjadi, diikuti dengan fatigue (22,5\%) dan stres $(22,3 \%)^{1}$.

Nyeri punggung bawah (NPB) merupakan masalah paling umum yang dialami banyak orang dalam kehidupan. Estimasi insidensi satu tahun dari awal timbulnya nyeri punggung bawah berkisar antara 1,5\% dan 36\%. ${ }^{2}$ Tinjauan terkini dari prevalensi nyeri punggung bawah pada populasi dewasa secara umum diterbitkan pada tahun 2000 dan menunjukkan prevalensi per tahun $22-65 \%^{3}$.

NPB juga merupakan penyebab utama terbatasnya aktivitas dan absen kerja di seluruh dunia, yang menggambarkan beban ekonomi pada individu, keluarga, komunitas, industri, dan pemerintah. Di Amerika Serikat, NPB diidentifikasi sebagai penyebab umum disabilitas pada dewasa muda, dengan lebih dari 100 juta hari kerja yang hilang per tahun. ${ }^{4}$

Pada kategori negara pendapatan rendah dan pendapatan tinggi, tingkat NPB bervariasi dua kali lipat atau lebih. Secara keseluruhan, NPB lebih tinggi pada populasi umum pada beberapa negara pendapatan tinggi dibandingkan daerah dengan pendapatan rendah, secara spesifik 2-4 kali lebih tinggi pada populasi di Swedia, Jerman, Belgia dibandingkan dengan petani Nigeria, Cina Selatan, Indonesia, dan Filipina. ${ }^{5}$

Data mengenai prevalensi WMSD maupun NPB di Indonesia tidak spesifik dibandingkan dengan data dari negara lain. Menurut hasil studi Departemen Kesehatan RI tentang profil masalah kesehatan di Indonesia tahun 2005 menunjukkan bahwa sekitar 40,5\% penyakit yang diderita berhubungan dengan pekerjaan. Menurut studi yang dilakukan terhadap 9.482 pekerja di 12 kabupaten kota di Indonesia, penyakit yang diderita umumnya berupa penyakit muskuloskeletal (16\%). ${ }^{6}$

\section{METODE PENELITIAN}

Jenis penelitian yang dilakukan ialah survei lapangan dengan desain potong lintang. Kuesioner yang digunakan ialah Nordic Body Map (Kuorinka et al, 1987), kuesioner paparan fisik (Widanarko), dan kuesioner psikososial (Karasek et al, 1998). Penelitian dilaksanakan pada bulan Oktober-Desember 2015 dan dilaksanakan di Sekolah Dasar di Kecamatan Tuminting. Populasi ialah guru sekolah dasar di Kecamatan Tuminting Kota Manado yang berjumlah 360 orang ssedangkan sampel diperoleh dari total sampling berdasarkan kriteria inklusi.

Kriteria inklusi meliputi guru laki-laki dan perempuan yang sudah menjadi guru Sekolah Dasar sekurang-kurangnya 12 bulan. Definisi operasional ialah variabel yang berhubungan dengan risiko NPB meliputi faktor individu, fisik, dan psikososial.

\section{HASIL PENELITIAN}

Tabel 4 memperlihatkan faktor individu yang berhubungan bermakna dengan NPB ialah kelas yang diajar ( $\mathrm{p}<$ 0,05 ) sedangkan faktor individu seperti umur, lama menjadi guru, jenis kelamin, pemberian kegiatan ekstrakurikuler dan merokok tidak berhubungan bermakna ( $p>$ 0,05).

Tabel 5 memperlihatkan faktor fisik yang berhubungan bermakna dengan NPB selama 7 hari ialah tangan di bawah lutut membungkuk >30 menit dan aktivitas waktu senggang selama 7 hari terakhir $(\mathrm{p}<$ $0,05)$ sedangkan faktor fisik seperti lama berdiri, duduk, membungkuk, aktivitas selama 7 hari terakhir, tidak berhubungan bermakna ( $p>0,05)$. 
Jurnal e-Biomedik (eBm), Volume 4, Nomor 2, Juli-Desember 2016

Tabel 4. Hasil hubungan faktor individu dengan nyeri punggung bawah

\begin{tabular}{|c|c|c|c|c|c|c|c|}
\hline \multirow{2}{*}{\multicolumn{2}{|c|}{ Faktor individu }} & \multicolumn{4}{|c|}{ yeri punggung bawah selama 7 hari terakhir } & \multirow[t]{2}{*}{ Total } & \multirow[t]{2}{*}{$\mathrm{p}$} \\
\hline & & $\begin{array}{l}\text { Tidak } \\
\text { pernah }\end{array}$ & $\begin{array}{c}\text { Satu atau } \\
\text { dua kali }\end{array}$ & $\begin{array}{l}\text { Kadang- } \\
\text { kadang }\end{array}$ & $\begin{array}{l}\text { Sering/ } \\
\text { selalu }\end{array}$ & & \\
\hline \multicolumn{8}{|c|}{ 1. Umur (tahun) } \\
\hline & $21-30$ & 5 & 9 & 13 & 8 & 35 & 0,772 \\
\hline & $31-40$ & 11 & 11 & 23 & 8 & 53 & \\
\hline & $41-50$ & 17 & 31 & 43 & 22 & 113 & \\
\hline & $>50$ & 19 & 14 & 32 & 16 & 81 & \\
\hline \multicolumn{8}{|c|}{ 2. Status gizi } \\
\hline & Kurang & 2 & 3 & 4 & 2 & 11 & 0,931 \\
\hline & Normal & 32 & 32 & 62 & 30 & 156 & \\
\hline & Lebih & 18 & 30 & 45 & 22 & 115 & \\
\hline \multicolumn{8}{|c|}{ 3. Lama menjadi guru } \\
\hline & $1-10$ & 18 & 23 & 42 & 16 & 99 & 0,699 \\
\hline & $11-20$ & 12 & 16 & 23 & 15 & 66 & \\
\hline & $21-30$ & 7 & 14 & 26 & 14 & 61 & \\
\hline & $>30$ & 15 & 12 & 20 & 9 & 56 & \\
\hline \multicolumn{8}{|c|}{ 4. Kelas } \\
\hline & 1 & 6 & 5 & 24 & 6 & 41 & $0,008^{*}$ \\
\hline & 2 & 8 & 19 & 12 & 8 & 47 & \\
\hline & 3 & 4 & 14 & 21 & 13 & 52 & \\
\hline & 4 & 12 & 11 & 16 & 9 & 48 & \\
\hline & 5 & 16 & 5 & 18 & 9 & 48 & \\
\hline & 6 & 6 & 11 & 20 & 9 & 46 & \\
\hline \multirow[t]{3}{*}{5.} & Jenis kelamin & & & & & & \\
\hline & Perempuan & 42 & 53 & 91 & 42 & 228 & 0,932 \\
\hline & Laki-laki & 10 & 12 & 20 & 12 & 54 & \\
\hline \multirow[t]{3}{*}{6.} & $\begin{array}{l}\text { Pemberian } \\
\text { ekstrakulikuler/les }\end{array}$ & & & & & & \\
\hline & Ya & 29 & 41 & 69 & 30 & 169 & 0,728 \\
\hline & Tidak & 23 & 24 & 42 & 24 & 113 & \\
\hline \multicolumn{8}{|c|}{$\begin{array}{l}\text { 7. Lama pemberian } \\
\text { ekstrakulikuler } \\
\text { (jam/minggu) }\end{array}$} \\
\hline & 0 & 23 & 25 & 42 & 25 & 115 & 0,838 \\
\hline & $1-5$ & 20 & 18 & 43 & 21 & 112 & \\
\hline & $>5$ & 9 & 12 & 26 & 8 & 55 & \\
\hline
\end{tabular}

Tabel 5. Hasil hubungan faktor fisik dengan nyeri punggung bawah

\begin{tabular}{|c|c|c|c|c|c|c|}
\hline \multirow[t]{2}{*}{ Faktor fisik } & \multicolumn{4}{|c|}{ Nyeri punggung bawah selama 7 hari terakhir } & \multirow[t]{2}{*}{ Total } & \multirow[t]{2}{*}{$\mathrm{p}$} \\
\hline & $\begin{array}{r}\text { Tidak } \\
\text { pernah }\end{array}$ & $\begin{array}{l}\text { Satu atau } \\
\text { dua kali }\end{array}$ & $\begin{array}{l}\text { Kadang- } \\
\text { kadang }\end{array}$ & $\begin{array}{l}\text { Sering/ } \\
\text { selalu }\end{array}$ & & \\
\hline \multicolumn{7}{|c|}{ 1. berdiri (menit/hari) } \\
\hline $1-30$ & 12 & 21 & 25 & 14 & 72 & 0,104 \\
\hline $30-60$ & 12 & 4 & 28 & 11 & 55 & \\
\hline$>60$ & 28 & 40 & 58 & 29 & 155 & \\
\hline \multicolumn{7}{|l|}{ 2. duduk (menit/hari) } \\
\hline $1-30$ & 12 & 13 & 26 & 29 & 66 & 0,825 \\
\hline $30-60$ & 13 & 23 & 34 & 34 & 85 & \\
\hline$>60$ & 27 & 29 & 48 & 48 & 131 & \\
\hline \multicolumn{7}{|c|}{ 3. membungkuk (menit/hari) } \\
\hline 0 & 18 & 21 & 41 & 19 & 99 & 0,275 \\
\hline $1-30$ & 31 & 30 & 58 & 27 & 146 & \\
\hline$>30$ & 3 & 14 & 12 & 8 & 37 & \\
\hline
\end{tabular}


Haumahu, Doda, Marunduh: Faktor risiko yang...

4. Membungkuk dan memutar punggung (menit/hari)

0
$1-30$
$>30$

$\begin{array}{ll}31 & 35 \\ 19 & 26 \\ 2 & \end{array}$

35
26
4

$\begin{array}{ccc}52 & 24 & 142 \\ 54 & 27 & 126 \\ 5 & 3 & 14\end{array}$

0,688

5. Posisi tangan di bawah lutut membungkuk lebih dari 30 menit/hari

Hampir tidak pernah

1-3 hari/bulan

Satu hari per minggu

2-4 hari/minggu

Setiap hari kerja

126

6. Aktivitas selama bekerja 7 hari terakhir

$\begin{array}{ll}\text { Pekerjaan berdiri } & 20 \\ \text { Pekerjaan duduk } & 11 \\ \text { Pekerjaan ringan } & 18\end{array}$

Pekerjaan ringan

Aktivitas diwaktu senggang

selama 7 hari terakhir

Bersantai dengan duduk

Latihan fisik secukupnya

Latihan fisik secukupnya dan teratur

Latihan fisik secara teratur dan berolahraga

\begin{tabular}{|c|c|c|c|c|}
\hline 19 & 40 & 25 & 104 & 0,775 \\
\hline 12 & 18 & 8 & 49 & \\
\hline 28 & 41 & 16 & 103 & \\
\hline 6 & 12 & 5 & 26 & \\
\hline 38 & 75 & 43 & 188 & $0,024^{*}$ \\
\hline 10 & 17 & 6 & 39 & \\
\hline 15 & 15 & 5 & 42 & \\
\hline 2 & 4 & 0 & 13 & \\
\hline
\end{tabular}

Tabel 6. Hasil hubungan faktor psikososial dengan nyeri punggung bawah

\begin{tabular}{|c|c|c|c|c|c|c|c|}
\hline & \multirow{2}{*}{$\begin{array}{l}\text { Faktor psikososial } \\
\text { Setuju/Tidak setuju }\end{array}$} & \multicolumn{4}{|c|}{ Nyeri punggung bawah selama 7 hari terakhir } & \multirow[t]{2}{*}{ Total } & \multirow[t]{2}{*}{$\mathrm{p}$} \\
\hline & & $\begin{array}{l}\text { Tidak } \\
\text { pernah }\end{array}$ & $\begin{array}{c}\text { Satu atau } \\
\text { dua kali }\end{array}$ & $\begin{array}{l}\text { Kadang- } \\
\text { kadang }\end{array}$ & ing/ selalu & & \\
\hline 1. & $\begin{array}{l}\text { Menghadapi tekanan terus } \\
\text { menerus karena beban kerja } \\
\text { yang tinggi. }\end{array}$ & & & & & & \\
\hline & Setuju & 5 & 13 & 24 & 17 & 59 & 0,052 \\
\hline & Tidak setuju & 47 & 52 & 87 & 37 & 223 & \\
\hline 2. & $\begin{array}{l}\text { Sering mendapatkan } \\
\text { interupsi dan gangguan } \\
\text { ketika bekerja. }\end{array}$ & & & & & & \\
\hline & Setuju & 8 & 11 & 21 & 22 & 62 & $0,003^{*}$ \\
\hline & Tidak setuju & 44 & 54 & 90 & 32 & 220 & \\
\hline 3. & $\begin{array}{l}\text { Selama beberapa tahun } \\
\text { terakhir, pekerjaan saya } \\
\text { semakin lama semakin } \\
\text { banyak (menuntut). }\end{array}$ & & & & & & \\
\hline & Setuju & 34 & 29 & 59 & 34 & 156 & 0,085 \\
\hline & Tidak setuju & 18 & 36 & 52 & 20 & 126 & \\
\hline 4. & $\begin{array}{l}\text { Dihargai dengan layak oleh } \\
\text { atasan atau orang-orang } \\
\text { yang berwenang. }\end{array}$ & & & & & & \\
\hline & Setuju & 51 & 64 & 104 & 51 & 270 & 0,356 \\
\hline & Tidak setuju & 1 & 1 & 7 & 3 & 12 & \\
\hline 5. & $\begin{array}{l}\text { Harapan kenaikan pangkat } \\
\text { saya buruk. }\end{array}$ & & & & & & \\
\hline & Setuju & 2 & 5 & 11 & 11 & 29 & $0,032 *$ \\
\hline & Tidak setuju & 50 & 60 & 100 & 43 & 253 & \\
\hline
\end{tabular}


6. Telah mengalami atau saya kira akan mengalami perubahan yang tidak menyenangkan di tempat kerja saya.

Setuju

Tidak setuju

$\begin{array}{cccccc}4 & 7 & 16 & 17 & 44 & 0,003^{*} \\ 48 & 58 & 95 & 37 & 238 & \end{array}$

7. Berdasarkan semua usaha dari prestasi saya, gaji/pendapatan saya telah sesuai.

Setuju

Tidak setuju

8. Saya mulai memikirkan masalah pekerjaan segera sejak bangun tidur.

$$
\text { Setuju }
$$

Tidak setuju

9.Pekerjaan saya mengharuskan saya belajar hal-hal baru.

$$
\text { Setuju }
$$

Tidak setuju

10. Pekerjaan saya memungkinkan saya untuk dapat mengambil keputusan sendiri dalam banyak hal.

$$
\begin{gathered}
\text { Setuju } \\
\text { Tidak setuju }
\end{gathered}
$$

11. Dalam bekerja, saya memiliki sangat sedikit kebebasan untuk menentukan bagaimana saya menyelesaikan tugas.

$$
\text { Setuju }
$$

Tidak setuju

12. Saya memiliki cukup waktu untuk menyelesaikan pekerjaan saya.

$$
\text { Setuju }
$$

Tidak setuju

13. Atasan saya memperhatikan apa yang saya katakan.

$$
\text { Setuju }
$$

Tidak setuju

14. Orang-orang yang bekerja dengan saya memiliki perhatian tentang hal pribadi saya

Setuju

Tidak setuju

15. Orang-orang yang bekerja dengan saya bersifat bersahabat

Setuju

Tidak setuju

$\begin{array}{lllcl}41 & 85 & 42 & 207 & 0,193 \\ 24 & 26 & 12 & 75 & \end{array}$

$65 \quad 109$


Haumahu, Doda, Marunduh: Faktor risiko yang...

\begin{tabular}{|c|c|c|c|c|c|c|c|}
\hline \multirow{2}{*}{\multicolumn{2}{|c|}{$\begin{array}{l}\text { Faktor psikososial } \\
\text { Puas/tidak puas }\end{array}$}} & \multicolumn{4}{|c|}{ Nyeri punggung bawah dalam 7 hari } & \multirow[t]{2}{*}{ Total } & \multirow[t]{2}{*}{$\mathrm{p}$} \\
\hline & & $\begin{array}{r}\text { Tidak } \\
\text { pernah }\end{array}$ & $\begin{array}{l}\text { Satu atau } \\
\text { dua kali }\end{array}$ & $\begin{array}{c}\text { Kadang- } \\
\text { kadang }\end{array}$ & $\begin{array}{r}\text { Sering/ } \\
\text { selalu }\end{array}$ & & \\
\hline \multicolumn{8}{|c|}{$\begin{array}{l}\text { 1. Seberapa puas Anda } \\
\text { dengan prospek pekerjaan } \\
\text { Anda? }\end{array}$} \\
\hline & Puas & 49 & 62 & 106 & 46 & 263 & 0,071 \\
\hline & Tidak puas & 3 & 3 & 5 & 8 & 19 & \\
\hline \multirow{2}{*}{\multicolumn{8}{|c|}{$\begin{array}{l}\text { 2. Seberapa puas anda } \\
\text { dengan kondisi fisik } \\
\text { lingkungan kerja Anda? }\end{array}$}} \\
\hline & & & & & & & \\
\hline & Puas & 38 & 47 & 90 & 30 & 205 & $0,008^{*}$ \\
\hline & Tidak puas & 14 & 18 & 21 & 24 & 77 & \\
\hline \multicolumn{8}{|c|}{$\begin{array}{l}\text { 3. Seberapa puas Anda } \\
\text { dengan pekerjaan/jabatan } \\
\text { Anda secara keseluruhan? }\end{array}$} \\
\hline & Puas & 49 & 58 & 106 & 46 & 259 & 0,104 \\
\hline & Tidak puas & 3 & 7 & 5 & 8 & 23 & \\
\hline \multicolumn{8}{|c|}{$\begin{array}{l}\text { 4. Secara umum, bagaimana } \\
\text { pekerjaan Anda? } \\
\text { Sama sekali tidak stres }\end{array}$} \\
\hline & Stres ringan & 34 & 37 & 62 & 19 & 152 & 0,068 \\
\hline & Stres sedang & $\begin{array}{c}15 \\
3\end{array}$ & $\begin{array}{c}24 \\
4\end{array}$ & $\begin{array}{c}43 \\
6\end{array}$ & $\begin{array}{c}32 \\
3\end{array}$ & $\begin{array}{c}114 \\
16\end{array}$ & \\
\hline
\end{tabular}

Tabel 6 memperlihatkan faktor psikososial yang berhubungan bermakna dengan NPB selama 7 hari terakhir pada guru Sekolah Dasar di Kecamatan Tuminting ialah: interupsi/gangguan saat mengajar, harapan kenaikan pangkat yang buruk, mengalami perubahan yang tidak menyenangkan, dan dari tingkat kepuasan, yaitu kepuasan lingkungan kerja $(p<0,05)$ sedangkan faktor psikososial lain tidak berhubungan signifikan $(\mathrm{p}>0,05)$.

\section{BAHASAN}

Hasil penelitian dengan kuesioner kepada 360 responden dan yang kembali dan termasuk dalam kategori inklusi sebanyak 282 responden. Respond rate pada penelitian ini sebesar $78 \%$ dan persentase NPB pada responden $81 \%$. Dari hasil penelitian ini, faktor risiko yang berhubungan ialah kelas yang diajar, aktivitas waktu senggang, dan dari segi psikososial ialah harapan kenaikan pangkat yang buruk, perubahan yang tidak menyenangkan di tempat kerja, dan tingkat kepuasan pada lingkungan fisik kerja. Banyak faktor risiko lain yang tidak berhubungan secara statistik diantaranya jenis kelamin, umur, tingkat pendidikan, maupun dari segi psikososial yaitu tekanan terus-menerus, dihargai dengan layak oleh rekan dan atasan, dan hubungan baik dengan rekan kerja sesama guru.

Pada penelitian ini faktor kelas yang diajar berhubungan dengan NPB. Prevalensi nyeri punggung tertinggi pada penelitian ini ialah pada guru kelas tiga SD. Hal ini mungkin disebabkan karena usia 89 tahun merupakan saat dimana tumbuh dan berkembang sehingga mereka lebih suka berlarian dan sulit diatur. Sebuah penelitian oleh Nilahi ${ }^{7}$ untuk mencari tahu NPB terkait pekerjaan pada guru sekolah dasar di Tanzania menemukan bahwa prevalensi nyeri punggung bawah terkait dengan jumlah waktu belajar dalam satu hari. Semakin lama waktu belajar per hari, semakin tinggi pula prevalensi nyeri punggung pada guru. Hal ini sesuai dengan hasil penelitian ini, bahwa tentunya pada kelas tiga, empat dan lima, jumlah waktu belajarnya lebih banyak dibandingkan kelas satu dan dua SD.

Pada penelitian ini juga ditemukan 
bahwa aktivitas waktu senggang berhubungan dengan nyeri punggung bawah. Penggunaan gadget pada zaman sekarang mungkin saja memengaruhi kebiasaan para guru saat tidak sedang mengajar dan bersantai di rumah yaitu dengan duduk berjam-jam memainkan gadget. Jika duduk terlalu lama dengan postur tubuh yang tidak benar, maka akan meningkatkan risiko nyeri punggung, karena akan menyebabkan ketegangan otot dan keregangan ligamentum sehingga menimbulkan tekanan abnormal. ${ }^{8}$ Omokhodion dan Sanya $^{9}$ berpendapat bahwa duduk lebih dari tiga jam per hari dapat meningkatkan risiko nyeri punggung, namun $\mathrm{Lis}^{10}$ dalam penelitiannya mengatakan bahwa faktor duduk saja tidak meningkatkan risiko NPB, tetapi duduk lebih dari setengah dari waktu kerja, dikombinasikan dengan getaran seluruh badan (biasanya ditemukan pada supir, pekerja tambang, atau pekerja bangunan) dan atau postur tubuh yang kurang nyaman, merupakan peningkatan tertinggi untuk terjadinya NPB.

Postur tubuh berpengaruh terhadap terjadinya nyeri punggung bawah. Dalam penelitian ini, didapatkan terdapat satu hasil yang bermakna, yaitu membungkuk dengan tangan di bawah lutut lebih dari 30 menit. Menurut Tsuboi et al. ${ }^{11}$ penggunaan kekuatan otot yang tiba-tiba dan berlebihan dapat berpengaruh pada serangan nyeri punggung bawah

Faktor psikososial berperan penting dalam risiko terjadinya nyeri punggung bawah. Faktor psikososial yaitu tingkat kepuasan terhadap lingkungan fisik di tempat kerja berhubungan signifikan secara statistik. Penelitian yang dilakukan oleh Beyen et al. ${ }^{12}$ mengenai faktor risiko nyeri punggung bawah pada guru di Gondar, Etiopia menemukan bahwa ketersediaan ruangan kerja yang memadai berhubungan dengan risiko timbulnya NPB. Guru yang mempunyai ruangan memadai pada institusi lebih tidak mudah untuk terkena NPB dibandingkan dengan guru yang tidak mempunyai ruangan kerja ${ }^{12}$. Dari penelitian tersebut, dapat disimpulkan bahwa tingkat kepuasan terhadap lingkungan di tempat kerja berhubungan bermakna dengan timbulnya NPB. Pada NPB terdapat hipotesis bahwa paparan faktor psikososial dapat mengarah ke peningkatan kekakuan otot, termasuk diantaranya otot sekitar tulang belakang, yang dapat mempengaruhi nutrisi diskus intervetebra, akar saraf, dan jaringan sekitar tulang belakang lainnya ${ }^{13}$.

Faktor psikososial lainnya yang berhubungan ialah harapan kenaikan pangkat yang buruk dan perubahan tidak menyenangkan di tempat kerja. Kedua hal tersebut mungkin termasuk dalam ketidakpuasan dalam pekerjaan (job dissatisfaction). Bigos et al. dan Skovron et al. menemukan bahwa job dissatisfaction merupakan faktor risiko signifikan terhadap terjadinya nyeri punggung bawah. ${ }^{14}$

Faktor jenis kelamin tidak berhubungan bermakna secara statistik dalam penelitian ini. Hal ini sejalan dengan penelitian yang dilakukan oleh Yue et al. ${ }^{15}$ yang menemukan bahwa jenis kelamin tidak berhubungan dengan nyeri punggung bawah. Perbedaan jenis kelamin dapat dijelaskan karena berbagai faktor, diantaranya pria lebih cenderung lebih sering berolahraga, sedangkan wanita yang berprofesi sebagai guru lebih banyak menghabiskan waktu mengurus keluarga di rumah.

Tingkat pendidikan juga tidak berhubungan bermakna dalam penelitian ini. Hal ini berbeda dengan penelitian yang dilakukan oleh Erick dan Smith ${ }^{16}$ di Botswana, hasil penelitian yang didapatkan ialah terdapat hubungan bermakna antara tingkat pendidikan guru dan NPB.

Pada penelitian ini didapatkan status gizi tidak berhubungan bermakna. Penelitian yang dilakukan Abdulmonem et al. ${ }^{17}$ juga menunjukkan hasil yang tidak bermakna antara indeks massa tubuh (IMT) dengan nyeri muskuloskeletal. Telah diketahui bahwa peningkatan IMT sendiri berhubungan positif dengan herniasi diskus lumbar, yang merupakan penyebab penting NPB. ${ }^{18}$ 


\section{SIMPULAN}

Dari hasil penelitian terhadap faktor risiko nyeri punggung bawah pada guru Sekolah Dasar di kecamatan Tuminting, didapatkan bahwa faktor-faktor yang berhubungan ialah: faktor individu yaitu kelas yang diajar, faktor fisik meliputi tangan di bawah lutut membungkuk lebih dari 30 menit saat mengajar serta aktivitas waktu senggang selama 7 hari terakhir, dan faktor psikososial yaitu interupsi/gangguan saat mengajar, harapan kenaikan pangkat yang buruk, mengalami perubahan yang tidak menyenangkan di sekolah, dan kepuasan lingkungan kerja.

\section{SARAN}

Disarankan pada penelitian selanjutnya agar dapat menjelaskan teknik pengisian kuesioner dengan baik sehingga data yang didapatkan menjadi lebih akurat. Selain itu juga mencari tahu faktor risiko pada para dosen terutama terkait pemakaian high heels terhadap risiko nyeri punggung bawah.

\section{DAFTAR PUSTAKA}

1. Nunes IL, Bush PM. Work-related musculoskeletal disorders Assessment and prevention. 2012 April 2012 [cited 2015 Sep 25]. Available from: http://cdn.intechopen.com/pdfswm/35811.pdf

2. Hoy D, Brooks P, Blyth F, Buchbinder R. The epidemiology of low back pain. 2010 Dec [cited 2015 Oct 4]. Available from: http://www.ncbi.nlm.nih.gov/pubmed $/ 21665125$

3. Hoy D, Bain C, Williams G, March L, Brooks P, Blyth F, et al. A systematic review of the global prevalence of low back pain. Arthitis Rheum. 2012;64:2028-37.

4. World Health Organization. Low Back Pain. 2013 March 15 [cited 2015 Sep 25]. Available from: http://www.who.int/medicines/areas/p riority_medicines/Ch6_24LBP.pdf

5. Volinn E. The epidemiology of low back pain in the rest of the world: A review of surveys in low- and middle-income countries. Spine J. 1997;22:1747-54.

6. Munir S. Analisis nyeri punggung bawah pada pekerja Bagian Final Packing dan Part Supply di PT.X tahun 2002. 2012 July [cited 2015 Oct 6]. Available from: http://lib.ui.ac.id/file?file=digital/203 13339-T\%2031724-

Analisis\%20nyeri-full\%20text.pdf

7. Nilahi C. Work-related lower back pain among primary school teachers in Dar es Salaamn Tanzania. University of the Western Cape Repository. 2014 Nov [cited 2016 Jan 12]. Available from: http://etd.uwc.ac.za/xmlui/handle/113 94/4187

8. Sullivan PB, Mitchell T. The relationship between posture and back muscle endurance in industrial workers with flexion-related low back pain. 2011 Nov [cited 2015 Oct 5]. Available from:

http://www.researchgate.net/publicati on/7788564_The_relationship_bewee n_posture_and_back_muscle_endura nce_in_industrial_workers_with_flexi on-related_low_back_pain

9. Omokhodion F, Sanya A. Risk Factors for low back pain among office workers in Ibadan, Southwest Nigeria. Occup Med. 2003;53:287-89.

10. Lis A, Black $\mathbf{K}$, Korn $\mathbf{H}$, Nordin $\mathbf{M}$. Association between sitting and occupational LBP. Eur Spin J 2007;16:283-98.

11. Tsuboi H, Takeuchi K, Misuzu W, Hori R, Kobayashi F. Psychosocial factors related to low back pain among school personnel in Nagoya, Japan. Industrial Health. 2002;40266-71.

12. Beyen T, Mengestu M, Zele Y. Low back pain and associated factors among teachers in Gondar Town, North Gondar, Amhara Region, Ethiopia. Occup Med Health Affairs. 2013;1: 127.

13. Hartvigsen J, Lings S, Lebouefu-Yde C, Bakketeig L. Psychosocial factors at work in relation to low back pain and consequences of low back pain; a systematic, critical review of prospective cohort studies. 2003 July 2 [cited 2015 Oct 7]. Available from: 
http://oem.bmj.com/content/61/1/e2.f ull.pdf

14. Thorbjornsson CO, Alfredsson L, Frediksson K, Koster M, Michelsen $\mathrm{H}$, Vingard E, et al. Psychosocial and physical risk factors associated with low back pain: a 24 year follow up among women and men in a broad range of occupations. Occup Environ Med. 1998;55:84-90.

15. Yue P, Liu F, Li L. Neck/shoulder pain and low back pain among school teachers in China, prevalence and risk factors. BMC Public Health. 2012;12:789.
16. Erick P, Smith D. Low back pain among school teachers in Botswana, prevalence and risk factors. BMC Musculoskeletal Disorders. 2014;15:359

17. Abdulmonem A, Hanan A, Elaf A, Haneen T, Jenan A. The prevalence of musculoskeletal pain and its associated factors among female Saudi school teachers. Pak J Med Sci. 2014;30:1191-9.

18. Price SA, Wilson LM. Patofisiologi: Konsep Klinis Proses-Proses Penyakit (6th ed). Jakarta: EGC, 2012; p. 1. 